\title{
THE CORRELATION BETWEEN URBAN OPEN SPACE OCCUPATION DIFFERENCES AMONG GENERATIONS X, Y, AND Z AND OCCUPANT WELL-BEING
}

\author{
DÜZENLI, T. ${ }^{*}-$ ALPAK, E. M. - YILMAZ, S. \\ Department of Landscape Architecture, Forestry Faculty, Karadeniz Technical University \\ Trabzon, Turkey \\ *Corresponding author \\ e-mail: tugbaduzenli@gmail.com \\ (Received 25 ${ }^{\text {th }}$ Dec 2018; accepted 20 ${ }^{\text {th }}$ Feb 2019)
}

\begin{abstract}
As spatial occupants, humans expect the space to be designed to meet their needs and satisfy their goals. Thus, designers should identify the changing spatial uses and preferences of several different groups. The present study aimed to determine intergenerational differences among generations $\mathrm{x}, \mathrm{y}, \mathrm{z}$ in their preferences in open space occupation and activities and their well-being levels based on occupation types. The study was conducted in Trabzon province in Turkey. It aimed to determine the occupation types for different generational groups in urban open spaces. For this purpose, a survey was conducted with 70 individuals from each generation $(\mathrm{x}, \mathrm{y}, \mathrm{z})$, a total of 210 individuals in urban open spaces and their well-being levels were determined based on their occupational objectives and usage. The analyzes and tests conducted on the collected data demonstrated that the generations $\mathrm{x}, \mathrm{y}$, and $\mathrm{z}$ had different objectives and conducted different activities in open urban spaces. It was determined that generation $\mathrm{x}$ used the urban open spaces for sitting, resting, chatting, reading newspapers, etc. activities, generation y used the urban open spaces for meeting their peers, socialization, shopping, eating-drinking, etc. activities, while generation $\mathrm{z}$ occupied the urban open spaces for activities such as entertainment, sports, spending time with friends, meeting, etc. It was found that when they spent time in spaces that offer adequate activities, the level of well-being improved. It was concluded that different generations occupied outdoor spaces for different purposes, performed different activities in these spaces and their well-being improved when they spend time in adequate spaces.
\end{abstract}

Keywords: age groups, activities, preferences, outdoor spaces

\section{Introduction}

The group of individuals that were born in a particular period of time is called a generation. Generation is defined as a group of people who were born during the same period, sharing similar age, experiencing similar problems, fate and responsibilities. Sociological definitions of generation describe the concept as group of individuals who were born in certain period, affected by similar social, political and economic factors in the socialization process, assumed similar responsibilities due to similar conditions, and thus share common values, beliefs, expectations and behavior (Kon, 2017; Alpak et al., 2018; Glass, 2007; Inglehart, 1997). Nowadays, the term generation is generally used to emphasize the social or cultural structure of a period. Differences between generations are evident in every century, every period, and every époque. Intergenerational conflicts led to important social problems, the attempt of older generations to understand the new ones is very important for the society to live together and occupy a common space.

Auguste Comte initiated the scientific research on generation studies between 1830 and 1840. Comte suggested that generational deviations are forces that evolve in the historical process and social progress is possible only with the knowledge that one generation would transfer to the next (Comte, 1974). As the generations age, the behavioral characteristics of 
individuals differ. This is called the ageing effect and explains the different behavior of different generations within the same timeframe. Each generation has its own history and knowledge that distinguishes it from other generations. This difference stems from the socio-cultural and political legacy of previous generations (Toruntay, 2011; Dereli and Toruntay, 2015).

Strauss and Howe (1991), who conducted generation studies based on the work by John Stuart Mill, August Comte and Karl Manheim, used the following criteria to describe the concept of generations:

- There should be a common historical period shared by the members of a generation. These individuals experience similar historical events and social trends when living the same periods of their lives.

- Generation members tend to share behavior and common beliefs, including attitudes such as taking risks, culture, values, professional and domestic life that were shaped by their experiences in childhood or adulthood.

- They are aware of the experiences and skills they share with their peers and share this belonging with the members of the same generation. Several studies demonstrated that individuals in different generations define the traits of their generation as original and unique, although these traits are not observed as such by others. Known and frequently used generations in recent history are classified as follows:

- Traditionalists1925-1945 (Lehto vd, 2006).

- Baby boomers 1946-1964 (Pekala, 2001), 1944-1960 (Arsenault, 2004) and 1943-1960 (Families \& Work Institute, 2002), 1945-1965(Roberts and Manolis, 2000; O’Bannon, 2001; Smola and Sutton, 2002; Wallace, 2006).

- Generation X 1966-1979 (Alwin, 2002; Roberts and Manolis, 2000; Smola and Sutton, 2002; Wallace, 2006).

- Generation Y (Millennials) 1980-2001 (Lower, 2008), 1980-1995 (Cogin, 2012).

- Generation Z (Millennial/Internet Generation) 2000-2020 (Haeberle et al., 2009; Kuran, 2010).

The classification of the generations in the 21st century included traditionalists, baby boomers, generations $\mathrm{X}, \mathrm{Y}$ and $\mathrm{Z}$. Individuals' perceptions, expectations, priorities, perspectives on life, and ultimately their behavior vary based on time. The fact that individuals born on similar timeframe have similar characteristics and each generation have distinct characteristics led to the studies on the concept of generation and the characteristics of generations (Davis et al., 2006; Adigüzel et al., 2014). Currently, there are at least 3 generations that must spend time together and occupy the urban spaces as peers. The conflicts between these generations are undoubtedly an important social issue. As spatial occupants, humans expect the space to be designed to meet their needs and satisfy their goals. Thus, designers should identify the changing spatial uses and preferences of several different groups. Children, young individuals and adults, i.e., generations $\mathrm{x}, \mathrm{y}$, and $\mathrm{z}$ are groups of occupants with different ages whose needs should be identified.

Ultimately, different generations have different demands, requirements and preferences. It is important to determine the differences between the generations to construct suitable designs for the occupants and create open spaces that the occupants could use, heal the occupants and increase their prosperity (Zhang et al., 2018). The present study aimed to determine the different needs of the generations $\mathrm{x}, \mathrm{y}$ and $\mathrm{z}$ and the differences in outdoor 
space use among these generations. Determination of the different uses and activities by different generations in urban open spaces was also aimed in the present study. Thus, design criteria for the open space occupancy by different generations were determined to design therapeutic and prosperous spaces for the occupants in order for the spaces to attract individuals of all current generations.

\section{Generation $X$ and its attributes}

The generation $\mathrm{x}$ was defined as the generation born between 1965 and 1978 (Okay, 2001) in certain resources and between 1961 and 1980 (Arsenault, 2004) and between 1965 and 1979 (Families and Work Institute: 2002) in others. This generation was raised in a world where the economy was in decline and a completely different value system was constructed (Acar, 2010). The decisive events for this generation were the Challenger Disaster in the US, divorces, AIDS, Sesame Street, MTV, Game Boy, and the first personal computers (Pekala, 2001). X generation possess a lower level of communication skills and technology knowledge when compared to younger generations (Elmore, 2011; Jianrui, 2011). Their technology knowledge is generally limited to general skills such as e-mailing and online job search. They are usually children of working parents and are defined as "latchkey kids" in various studies since they grew up with house keys hanging on their necks (FWI, 2002). They learned to grow up on their own and going home from school alone (Toruntay, 2011).

In this period, oil crisis, economic shocks, the generation of ' 68 , university revolts, political conflicts and television were the most important events in Turkey. Women began to participate in the labor activities in this period in Turkey. Parents started to have fewer children for a better life. They focused more on finance and individualism gained importance (Mengi, 2011).

Generation $\mathrm{x}$ is often described as indifferent and aimless. Researchers argued that this may be due to a phenomenon derived from a collective cynicism among Generation X, a generation who witnessed more violent and negative events with the introduction of television into homes (Wolburg, 2001; Smola and Sutton, 2002).). They tend to take more risks and question authorities such as common rituals and traditions when compared to previous generations, as well as being family-oriented, self-confident, open-minded and fun-loving (Zhang and Bonk, 2010; Etlican, 2012). Generation X is defined as a generation that is compliant with the rules, with a strong sense of belonging, respect for authority, loyal and hardworking. this age range, they experienced a feeling of alienation as a result of being the first generation to witness the divorce of their parents (Montana and Petit, 2008). According to Elmore (2011), members of Generation X do not endeavor to understand other generations. They usually work to live. Furthermore, this generation witnessed a number of inventions and discoveries. The members of the generation $\mathrm{X}$, who opened their eyes to the world with washing machines with a roller press, transistor radios, cassette players and turntables, experienced several transformations. Specifically, they tried to adapt to the transformation to computer systems and the changing business processes due to technological advances. Today, they are $22 \%$ of the population in Turkey (URL 2).

\section{Generation $Y$ and its attributes}

The generation y was defined as the generation born between 1981 and 2000 in certain resources (Arsenault, 2004), between 1980 and the present (Families and Work Institute, 2002), between 1979 and 2001 (Pekala, 2001), and between 1982 and 2004 (Strauss and 
Howe, 1997) in others. This generation has different names such as Millennials, Generation Next, Digital Generation, Echo Boomers and Nexters (Morgan and Ribbens, 2006).

The principal events of the period that affected the generation y in Turkey included increasing terrorist acts, the Gulf War, Iraq War, the Internet, globalization and mobile phones (Aktan, 2011). Similar to generation x, generation y had working parents. However, the age of parenthood increased to 27. This generation, which had quite different parents when compared to previous generations, had more active parents who had a more active role in raising their children under better conditions, their education and safety. Members of Generation Y are the children of parents who regularly check the children's grades, question bad grades, meet their teachers, and visit the school frequently. The generation y, who had to defend themselves against their parents constantly on issues they failed, learned how to deal with the system at an early age (Wendover, 2001; Zempke et al., 2013).).

Generation Y, the busiest generation ever, were raised with micro programs by their overprotective parents and grew up within close relationships, however they are still the most stressed generation ever (Raines, 2002). In the literature, the parents who monitor this generation closely and are constantly around are called "Helicopter Parents" (Howe and Strauss, 2007). Globalization also had a great impact on this generation. This generation is the first generation to be born to Internet with the highest daily interaction with different ethnicities and cultures, and its members possess more cultural richness when compared to previous generations. They grew up under the media and commercial influences since their birth, and thus possess higher brand awareness when compared to their parents. When the economic conditions of the members of this generation are compared, it is observed that the difference between the members with high and low purchase power is the greatest among the studied generations (Toruntay, 2011). Sheahan (2005) defined the generation y as the generation that could easily express their thoughts and emotions, who love social relationships and with high emotional intelligence.

This generation in Turkey that includes young adults who are free-spirited, adaptable, fickle, well-educated, technology-oriented and like to defy the authority live in a period where the impact of globalization are felt intensely and economic and intercultural interaction is at a maximum due to the facilities available (Türk, 2013). It was claimed that this generation is approximately three times larger than the Generation X (Schroder and Warren, 2005). 35\% of the population living in Turkey currently are the members of this generation (TUDK). In Turkey, there are more Generation Y members when compared to the total population in several European countries (Toruntay, 2011).

\section{Generation $Z$ and its attributes}

This generation is believed to include individuals who are born between 2000 and 2020 and will join the labor force within the next 5 years (Kuran, 2010).

Generation $\mathrm{Z}$ children live in a society where novel technological means of communication and transportation are in abundance. They could communicate with each other via verbal or even visual communication using digital tools even when they live far away. The members of this generation play with tablet computers instead of toys, are fastconsuming, and have the ability to multitask. Unlike previous generations, although they are considered as 'network' youth, they are estimated to be physically alone and tend to live alone since they could communicate in long distance. Since their multitasking skills are extremely developed, they are considered as the generation with the highest motor skill synchronization such as manual, sight and auditory skills (Toruntay, 2011). According to 
Senbir (2004), this generation would be open to technology, and will not consider technology as a tool, but as a natural part of life.

However, it is considered that these advantages could turn into disadvantages due to attention and concentration difficulties. They like creative activities. Their long-term memory could be activated through games, storytelling and imagination rather than memorization. They are result oriented. Since the members of this generation are unsatisfied, unstable and innate consumers, it is considered that the concept of authority is not important in their lives. The networks they live in since their birth would play a major role in their identity.

This generation that includes the children born after 2000 in Turkey is also called the 'Crystal Generation'. Experts consider this generation as 'deeply emotional' and it includes $17 \%$ of the Turkish population (Adigüzel et al., 2014). It is estimated that the share of generation $\mathrm{z}$ in the Turkish population reached 18.000 .000 in 2015. Since they dislike hierarchy and are open to communications, it is considered that they would alter the organizational structures of the spaces they live in and work. Children who are the members of this generation expect everything to be personalized (Toruntay, 2011). The fact that their high education level, their independence and individuality would increase their creativity, their immediate honesty could lead to a motivated environment, the decrease in intergenerational differences, their social character and openness to communications, leading to a good understanding of each other, destruction of geographical borders due to the Internet, their higher self-expression levels could be considered among the positive attributes of this generation. Similarly, the disloyal, nondriven and unambitious, and fickle characteristics of the generation $\mathrm{z}$ and their desire to personalize everything could be considered among the negative attributes of this generation (Toruntay, 2011). It is also expected that they would have several diplomas and become experts, and would be innovative, malcontent and indecisive.

As a result, previous study findings demonstrated that there are different personality development, requirements and perceptions of these three generations. Thus, are the outdoor activities that these 3 generation occupants with different attributes conduct or desire to conduct different? The present study aimed to answer this question. Whether the well-being levels of the occupants increase when they spend time in spaces adequate for different activity requirements was another question that the present study aimed to respond.

\section{Materials and methods}

The study area included the outdoor spaces in the Eastern Black Sea Region and Trabzon province. Trabzon was established in early 2000's BC at the beginning of the historic Silk Road, which passes through Erzurum and reaches the Iranian border, connecting Europe and Asia. Trabzon, which is an important historical city, possesses several cultural assets due to its location. This led to the privileged position of Trabzon province among Eastern Black Sea Region provinces (Fig. 1).

\section{Application}

A survey was conducted with 210 Trabzon residents from the generations $\mathrm{x}, \mathrm{y}$, and $\mathrm{z}$ (70 individuals from each generation) in urban open spaces. The survey form included two sections. In the first section, different generation occupants were provided a list of activities 
and they were asked to mark the most frequent activity they conduct in open spaces. The second section was designed to determine the correlation between space occupancy and well-being of the occupants. In this section, the following statements were tested with 5point Likert attitude scale ( $5=$ very frequently, $1=$ never):

- I feel happy when I can conduct different activities that suit my needs in spaces.

- I feel happy when the spaces provide facilities for the activities I desire to conduct.

- I feel better in spaces that allow me to conduct active activities.

- I feel better in spaces that allow me to conduct passive activities.

- The activities I conduct in urban spaces make me happy.

Snowball sampling was used to select the survey participants. This method starts with the selection of a subject based on the research criteria and the other subjects are accessed using the initially selected subject. The subject is asked to recommend someone or some people with the same characteristics (Lawrence, 2016). Thus, individuals in the adequate generation were accessed and 210 individuals (70 in each generation) were interviewed. Initially, demographic data about the 210 participants were obtained, then the activity preference rates for the generations were determined and One-way ANOVA was conducted to determine the differences between the distribution of activity levels of the generations in urban open spaces. In the second stage, the questions asked to determine the correlation between the activities in open spaces and occupant well-being was analyzed separately for each generation and percentage and mean values are presented. Then, t-test statistics were applied to determine the distribution of well-being level for each generation $(\mathrm{x}, \mathrm{y}, \mathrm{z})$.

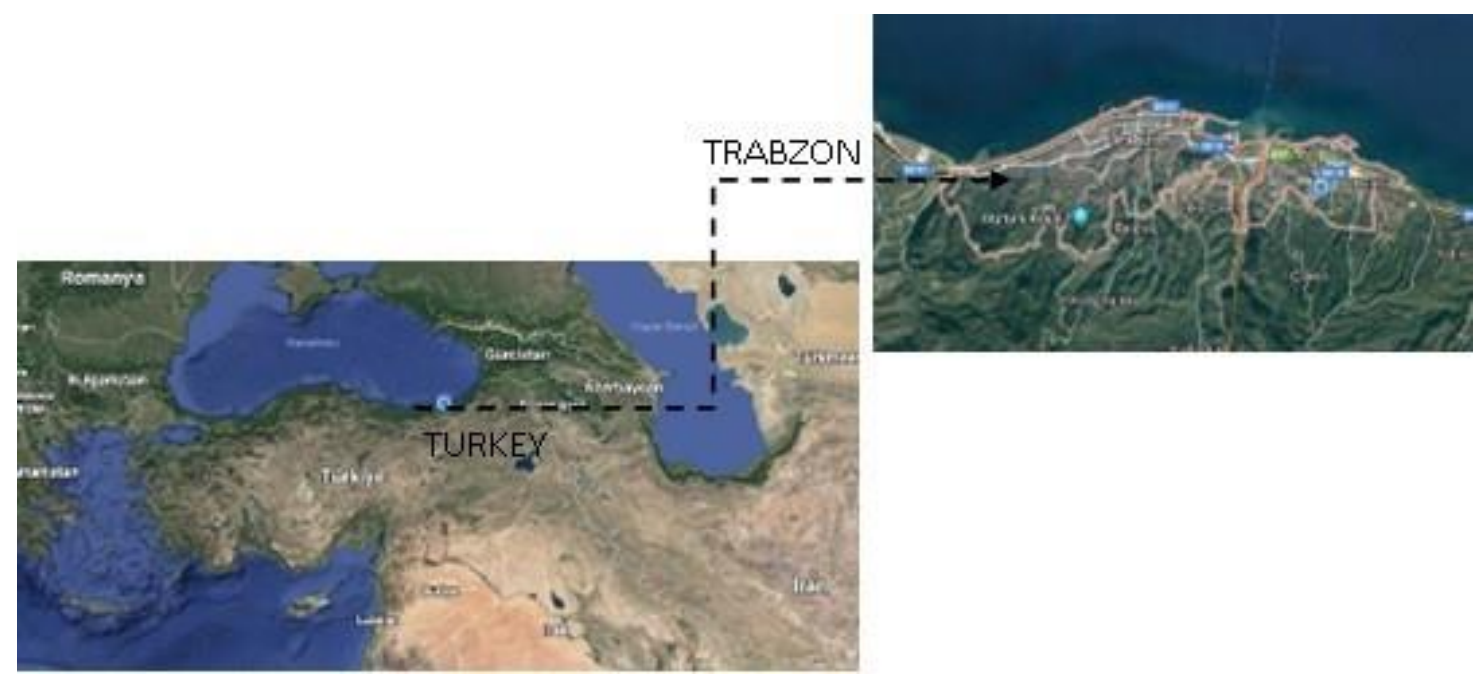

Figure 1. Study area

\section{Findings and discussion}

\section{Demographic findings}

The survey form included the age of the participants to determine their generation (Table 1). 
Table 1. Participant demographics

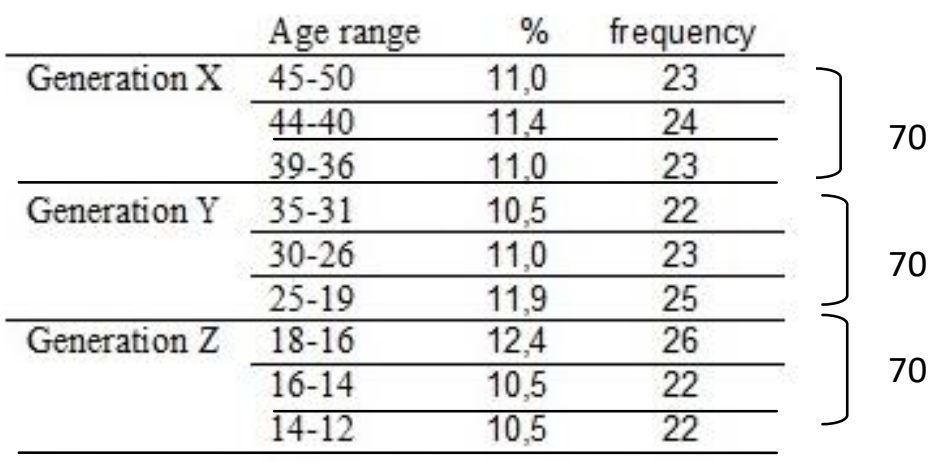

\section{Activity findings}

Gehl (1987, 2010) categorized the activities conducted in open spaces in three categories: compulsory activities, optional-selective activities and social activities:

- The compulsory activities include more or less obligatory and non-selective activities such as going to work, transportation, and waiting for someone. Since the activities in this group are mandatory, they occur under all conditions throughout the year. The participant has no right to choose.

- Optional activities are voluntary activities conducted when the time and space is suitable. The activities in this group take place only in favorable external conditions, when suitable whether and space are available. There is no obligation to conduct these activities and an individual conducts these activities compleyelt voluntarily such as taking a walk.

- Social activities take place based on the other two types of activities and are also called "eventual activities." Social activities are scrutinized in two categories: passive and active activities. Passive activities include short-lived and single superficial activities such as watching and listening to other people that one is not familiar with, watching the environment, reading newspapers or books, playing games such as backgammon, etc. (Gehl, 1987) These passive relations are important. Because the weak relationships established via the passive relations could be used as a first step in establishing a strong structural interaction (Peters et al., 2010). Active activities include activities where individuals interact with each other such as chatting, playing games, eating and drinking, sports, socializing, shopping and meeting.

In studies conducted to determine human behavior, attitudes and behavior, the optional and social activities that people conduct on their own without any requirement are investigated rather than the mandatory activities conducted without any choice. Various studies reported these activities conducted by occupants of various age groups in public open spaces (Bäckman and Rundqvist, 2005; Whtye, 1980; Mehta, 2007, 2009; Yuen and Chor, 1998; Kärrholm, 2008; Lofland, 1998). These activities included passive or active activities such as watching and listening to other people, talking, sitting with friends, chatting, reading newspapers, playing games, listening to street performers, etc. In the present study, behavior and attitudes of different generations, in other words age groups, were investigated. Thus, the present study scrutinized social and optional activities conducted in open spaces. The activities determined based on this 
criteria included 15 activities (going out with friends, spending time with peers, sittingresting, eating-drinking, spending time with family members, to breath the fresh air, shopping, walking, meeting with peers, viewing, reading books and newspapers, playing backgammon, playing games, socializing, having fun, playing sports, chatting) is provided in the question posed to determine the activities that the occupants from different generations conducted in urban open spaces and they were asked to mark the activity they conducted most. The highest value was observed for sitting-resting activity for generation $\mathrm{x}(22.9 \%)$. The highest value was observed for being with peers activity for generation y $(28.6 \%)$. The highest value was observed for sports activities for generation z (24.3\%) (Fig. 2).

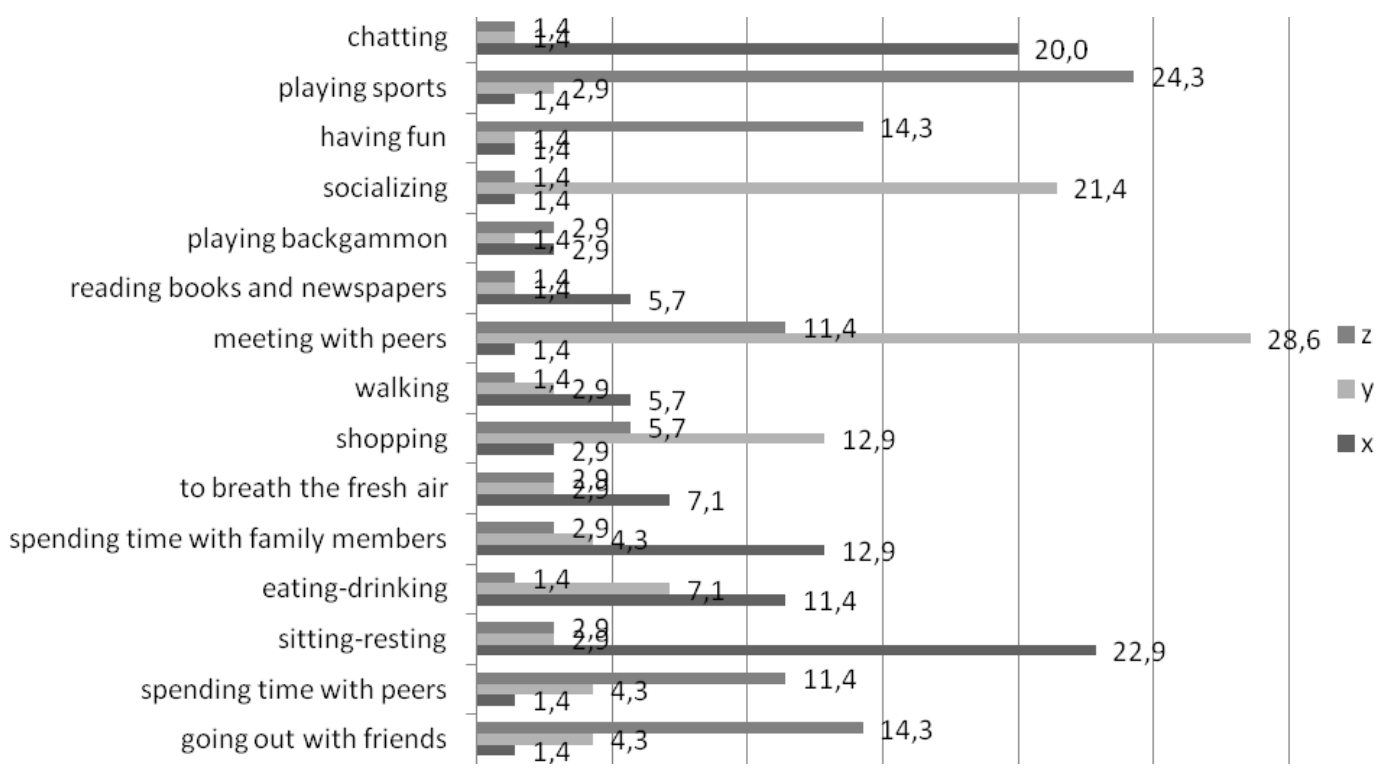

Figure 2. Activity distribution for generations $x, y$, and $z$

Since the age range of generation $\mathrm{x}$ includes adults who are more serene when compared to the new generations, the preference for passive activities such as sittingresting was higher among these individuals. According to Elmore (2011), members of the Generation X do not endeavor to understand generations other their own. The fact that they are inclined to conduct activities alone increases the possibility that they would be challenged in crowded activities. This could explain why they preferred passive activities in the study. It was observed that the generation y members preferred to be among peers the most, since they are between the ages of youth and adulthood and due to the social attributes of the generation. It could be suggested that the fact that their lives are generally fast, versatile and extremely intense (Zhang and Bonk, 2010) could be due to their environment of growth where these rapid changes occurred. Thus, they live in fast, active and crowded environments to meet their expectations. This explains the fact that they preferred social activities conducted with their peers in the study. Finally, generation $\mathrm{z}$ preferred active activities the most since this group includes the youngest individuals between childhood and youth and the sportive activities were the most preferred activities. Because this generation has high self-esteem, and the fact that their parents cherished them and considered them different increase their self-esteem. 
They are independent and free, there is nothing impossible for them (Haeberle et al., 2009). Thus, it was expected that they would prefer active activities in the study.

The One-Way ANOVA test conducted with SPSS (v. 17.0) software demonstrated that the distribution of the activity levels among different generations in urban open spaces was significant (Table 2).

Table 2. Distribution of urban open space activities based on generations

\begin{tabular}{c|c|c|c|c|c} 
& Sum of squares & df & Mean square & F & Sig. \\
\hline Between groups & 138.867 & 2 & 69.433 & 3.383 & .000 \\
Within groups & 4248.657 & 207 & 20.525 & & \\
Total & 4387.524 & 209 & & & \\
\hline
\end{tabular}

\section{Occupant well-being findings}

In order to determine the correlation between the open space activities and occupant well-being, the answers provided to 5 questions by each generation were analyzed separately.

The generation $x$ preferred to conduct passive activities with an average of 3.94, they were satisfied with the activities they conducted in urban outdoor spaces with an average of 3.80, they were satisfied with conducting various suitable activities with an average of 3.61, they stated that they were satisfied when the spaces allowed them to conduct the activities they desired with an average of 3.39, however their preference on conducting active activities was low with an average of 2.93. Since individualism and competitiveness are more important in this generation that prioritizes materialism (Reynolds et al., 2009), it was determined that they conducted more passive individual activities and their open space satisfaction was also high. The percentage graph for the answers of generation x members is presented in Figure 3.

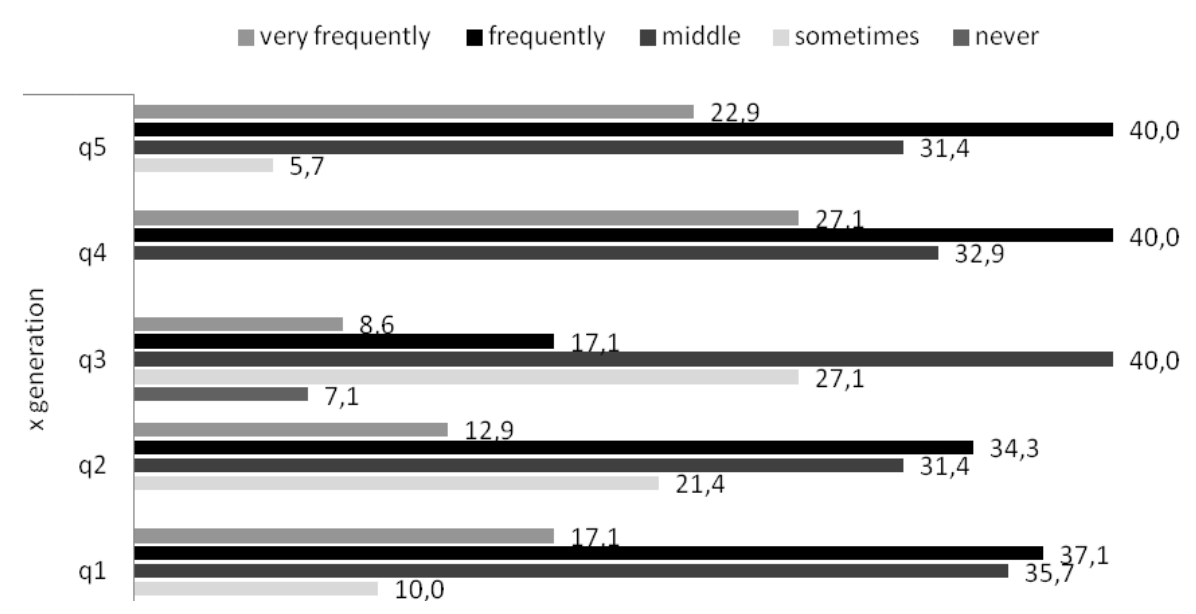

Figure 3. Percentages of the generation $x$ responses

Then, it was determined that the above-presented distribution of the generation $\mathrm{x}$ responses was significant based on the t-test results conducted with SPSS (v. 17.0) (Table 3). 
Table 3. Distribution of the generation $x$ responses

\begin{tabular}{c|c|c|c|c|c|c}
\hline & \multirow{2}{*}{$\mathbf{t}$} & \multirow{2}{*}{$\mathbf{d f}$} & $\begin{array}{c}\text { Sig. (2- } \\
\text { tailed) }\end{array}$ & $\begin{array}{c}\text { Mean } \\
\text { difference }\end{array}$ & \multicolumn{2}{|c}{$\begin{array}{c}\text { 95\% confidence interval of the } \\
\text { difference }\end{array}$} \\
\cline { 5 - 7 } & & & & & Lower & Upper \\
\hline s1 & 33.998 & 69 & .000 & 3.614 & 3.40 & 3.83 \\
s2 & 29.279 & 69 & .000 & 3.386 & 3.16 & 3.62 \\
s3 & 23.558 & 69 & .000 & 2.929 & 2.68 & 3.18 \\
s4 & 42.398 & 69 & .000 & 3.943 & 3.76 & 4.13 \\
s5 & 36.908 & 69 & .000 & 3.800 & 3.59 & 4.01 \\
\hline
\end{tabular}

It was determined that generation y was satisfied with the activities they conducted in urban outdoor spaces with an average of 3.96, preferred to conduct passive activities with an average of 3.56, they were satisfied with conducting various suitable activities with an average of 3.51, they preferred to conduct active activities with an average of 3.31, that is, the answers to all questions were at higher levels. As demonstrated with the literature review, peers and families are very important for Generation Y. They can come together very quickly due to their peer acceptance traits. This is the generation where the difference between the generations is felt the most. This is a technologyfriendly, individualist, entrepreneurial, comfortable and globalized generation. Changes in living conditions introduced different preferences for this generation (Zempke et al., 2013). In the present study, it was determined that urban outdoor spaces have positive effects on their preferences and increase their well-being levels. The percentage graph for the answers of generation y members is presented in Figure 4.

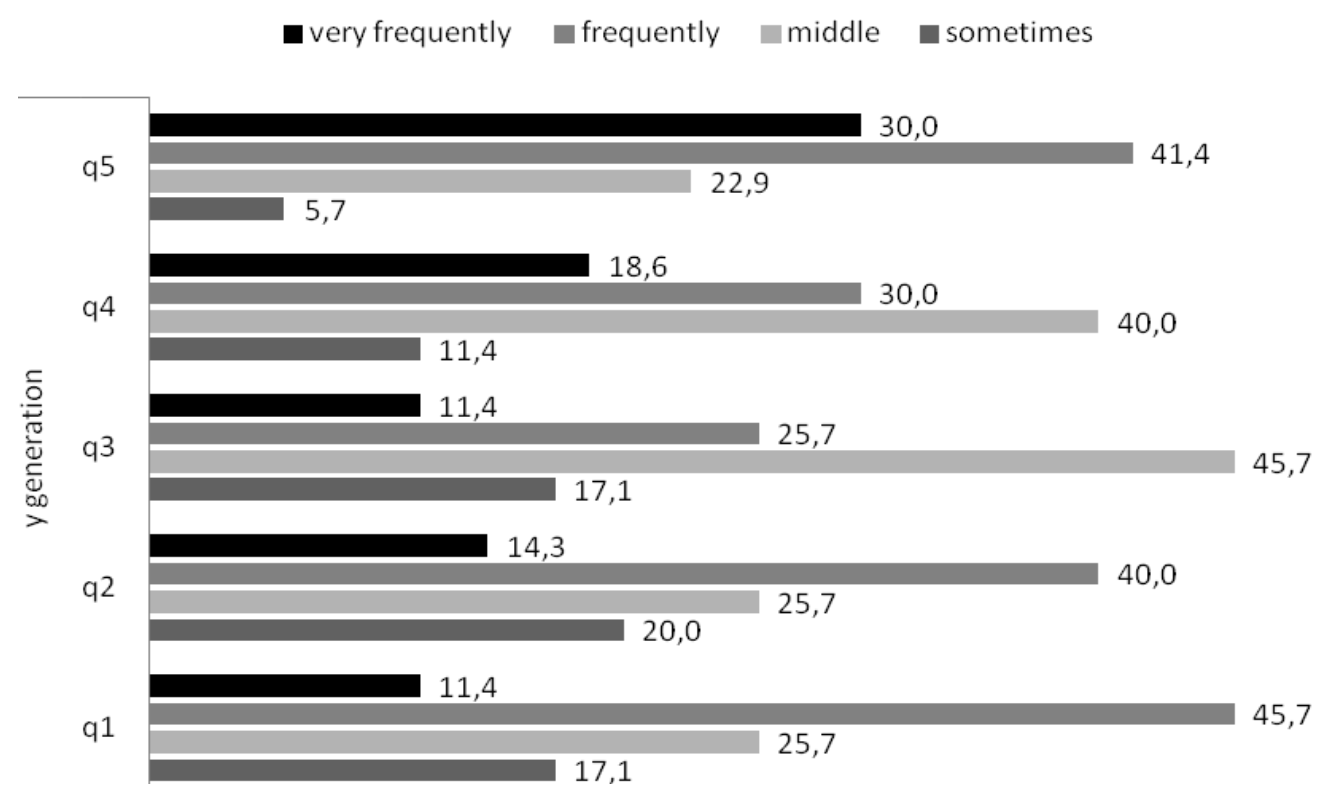

Figure 4. Percentages of the generation y responses 
Then, it was determined that the above-presented distribution of the generation $y$ responses was significant based on the t-test results conducted with SPSS (v. 17.0) (Table 4).

Table 4. Distribution of the generation y responses

\begin{tabular}{c|c|c|c|c|c|c}
\hline & \multirow{2}{*}{$\mathbf{t}$} & \multirow{2}{*}{$\mathbf{d f}$} & $\begin{array}{c}\text { Sig. (2- } \\
\text { tailed) }\end{array}$ & Mean difference & \multicolumn{2}{|c}{$\begin{array}{c}\text { 95\% confidence interval of the } \\
\text { difference }\end{array}$} \\
\cline { 5 - 7 } & & & & Lower & Upper \\
\hline s1 & 32.213 & 69 & .000 & 3.514 & 3.30 & 3.73 \\
s2 & 29.936 & 69 & .000 & 3.486 & 3.25 & 3.72 \\
s3 & 31.034 & 69 & .000 & 3.314 & 3.10 & 3.53 \\
s4 & 32.111 & 69 & .000 & 3.557 & 3.34 & 3.78 \\
s5 & 37.822 & 69 & .000 & 3.957 & 3.75 & 4.17 \\
\hline
\end{tabular}

It was determined that generation $\mathrm{z}$ preferred to conduct active activities with an average of 4.26, they were satisfied with conducting various suitable activities with an average of 4.06, satisfied with the activities they conducted in urban outdoor spaces with an average of 4.03 , they stated that they were satisfied when the spaces allowed them to conduct the activities they desired with an average of 4.00, and the responses to all questions were close to very high level, however their preference for passive activities was low with an average of 2.31. This was due to the fact that this generation is still very young and with active-mobile attributes. This generation is a fastconsuming generation. However, since they are familiar with the Internet, they are expected to develop the ability to deal with more than one subject at the same time (Senbir, 2004). The present study findings demonstrated that this generation preferred active activities due to their age group and they were happy when they conducted different activities and open spaces were effective on their well-being levels. The percentage graph for the answers of generation $\mathrm{z}$ members is presented in Figure 5.

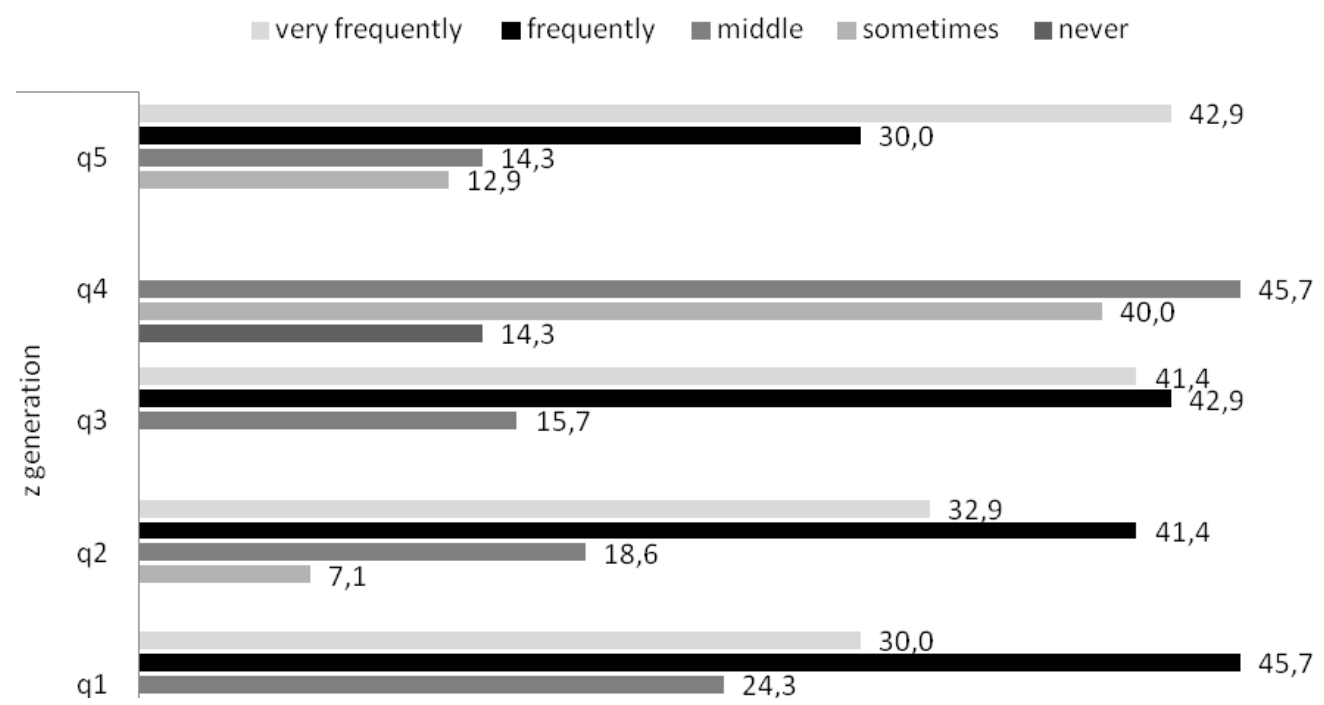

Figure 5. Percentages of the generation z responses to well-being questions 
Then, it was determined that the above-presented distribution of the generation $\mathrm{z}$ responses was significant based on the t-test results conducted with SPSS (v. 17.0) (Table 5).

Table 5. Distribution of the generation z responses

\begin{tabular}{c|c|c|c|c|c|c}
\hline & \multirow{2}{*}{$\mathbf{t}$} & \multirow{2}{*}{$\mathbf{d f}$} & $\begin{array}{c}\text { Sig. (2- } \\
\text { tailed) }\end{array}$ & $\begin{array}{c}\text { Mean } \\
\text { difference }\end{array}$ & \multicolumn{2}{|c}{ 95\% confidence interval of the difference } \\
\cline { 5 - 7 } & & & & & Lower & Upper \\
\hline s1 & 45.879 & 69 & .000 & 4.057 & 3.88 & 4.23 \\
s2 & 37.148 & 69 & .000 & 4.000 & 3.79 & 4.21 \\
s3 & 49.747 & 69 & .000 & 4.257 & 4.09 & 4.43 \\
s4 & 27.153 & 69 & .000 & 2.314 & 2.14 & 2.48 \\
s5 & 32.128 & 69 & .000 & 4.029 & 3.78 & 4.28 \\
\hline
\end{tabular}

\section{Conclusion and recommendations}

In conclusion, the present study conducted to determine open space occupancies of three generations with different desires, requirements and preferences revealed the following results:

- The generation x predominantly preferred passive outdoor activities such as sitting-resting,

- The generation y predominantly preferred social activities such as being with their peers,

- The generation z predominantly preferred more active activities such as sports.

- It was determined that all three generation members were happy when they conducted activities that were adequate for their needs and when the spaces allowed activities that were adequate for their desires.

- It was observed that urban open space activities were satisfactory for the members of all three generations and increased their well-being.

- Generation x felt better when they conducted passive activities, generation y felt better when they conducted both passive and active activities, and generation $\mathrm{z}$ felt better when they conducted active activities.

The different preferences and occupations determined based on the generations should be used to develop user-friendly designs and to create functional outdoor spaces that are therapeutic and increase the well-being of the occupants. The study investigated the different requirements of generations $\mathrm{x}, \mathrm{y}$ and $\mathrm{z}$ and to determine the differences between these generations in outdoor occupancy. The study also aimed to guide future designs by determining the outdoor occupancy types suitable for different generational groups and the activities preferred by these groups. The study findings are quite important to design open spaces that needs to be renewed, renovated or built and would appeal to all generations, thus would enable creation of adequate spaces to improve the health and well-being of the occupants. 


\section{REFERENCES}

[1] Adıgüzel, O., Batur, H. Z., Ekşili, N. (2014): Generation's Changing Side and The Newly Arısen Work Style After Y-Generation: Mobile Collars. - Journal of Süleyman Demirel University Institute of Social Sciences 1(19): 165-182 (Turkish).

[2] Aktan, C. C. (2011): Özal's change model and resistance to change analysis of power. Journal of Turkish Diary 40: 15-31 (Turkish).

[3] Alpak, E. M., Düzenli, T., Tarakci Eren, E.(2018): Urban identity and the influence of users on the place attachment: Trabzon City sample. - ASOS Journal 6: 519-528. (Turkish).

[4] Alwin, D. F. (2002): Generations X, Y and Z: are they changing America. - American Sociological Association. Contexts 42(1): 42-51.

[5] Arsenault, P. M. (2004): Validating generational differences. - The Leadership and Organization Development Journal 25: 2.

[6] Bäckma, M., Rundqvist, M. (2005): Social Space in a City of Life: The Case of Hanoi. Spatial Planning at Blekinge Institute of Technology. - Karslkrona, Sweden, pp. 47-90.

[7] Cogin, J. (2012): Are generational differences in work values fact or fiction? Multicountry evidence and implications. - The International Journal of Human Resource Management 23(11): 2268-2294.

[8] Comte, A. (1974): The Positive Philosophy. - Ams Press, New York.

[9] Davis, J. B., Pawlowski, S. D., Houston, A. (2006): Work commitments of Baby Boomers and Gen-Xers in the IT profession: generational differences or myth? - Journal of Computer Information Systems 46: 43-49.

[10] Dereli, B., Toruntay, H. (2015): Management of generations based on business values, motivation and mentoring. - İstanbul Ticaret Üniversitesi, Dış Ticaret Enstitüsü. Working Paper Series 03: 05 (Turkish).

[11] Elmore, L. (2011): Competing for jobs when you're up against your mum, your grandpa, and your pers. - Women in Business Summer, pp. 37-39.

[12] Etlican, G. (2012): Comparison of the attitudes of generation $x$ and $y$ to online training technologies - Master Thesis, Master Program of Human Resources Management, June 2012 (Turkish).

[13] Families and Work Institute (2002): Generation and Gender in the Workplace. American Business Collaboration, Waltham, MA.

[14] Gehl, J. (1987): Life between Buildings. - Van Nostrand-Reinhold, New York, pp. 11-31.

[15] Gehl, J. (2010): Cities for People. - Island Press, Washington, Covelo, London, pp. 7587.

[16] Glass, A. (2007): Understanding generational differences for competitive success. Industrial and Commercial Training 39: 98-103.

[17] Haeberle, K., Herzberg, J., Hobbs, T. (2009): Leading the multigenerational work force. Healthcare Executive 24(5): 62-67.

[18] Howe, N., Strauss, W. (2007): Helicopter Parents in the Workplace. - Syndicated Research Project. nGenera Insight, Talent 2.0, November.

[19] Inglehart, R. (1997): Modernization and Postmodernization: Cultural, Economic, and Political Change in 43 Societies. - Princeton University Press, Princeton, NJ.

[20] Jianru1, J. (2011): The Y factor: managing the new generation of soldiers. - Journal of The Singapore Armed Forces 39(4), 53-59.

[21] Kärrholm, M. (2008): The territorialisation of a pedestrian precinct in Malmö: materialities in the commercialisation of public space. - Urban Studies 45(9): 1903-1924.

[22] Kuran, E. (2010): Understanding Y Generation. - Symposium, Istanbul, 15. August 2010 (Turkish).

[23] Kuran, E. (2014): Understanding a Generation. - http://isyasami.yenibiris.com/yri-.aspx?pageID=238\&nID=70364\&NewsCatID=327\&AuthorID=152 (Turkish). 
[24] Lawrence, N. (2016): Social Research Methods 1. Qualitative and Quantitative Approaches. - Pearson, Boston, MA.

[25] Lehto, Y. X., Jang, S., Francis, A., O’Leary, J. (2008): Exploring tourism experience sought: a cohort comparison of baby boomers and the silent generation. - Journal of Vacation Marketing 14(3): 237-252.

[26] Lofland, L. (1998): The Public Realm: Exploring the City's Quintessential Social Territory. - Aldine De Gruyter, New York, pp. 25-71.

[27] Lower, J. (2008): Brace yourself, here comes generation Y. - Critical Care Nurse 28(5): 80-85.

[28] Mehta, V. (2007): Lively streets: determining environmental characteristics to support social behaviour. - Journal of Planning Education and Research 27: 165-187.

[29] Mehta, V. (2009): Look closely and you will see, listen carefully and you will hear: urban design and social interaction on streets. - Journal of Urban Design 14(1): 29-64.

[30] Montana, P. J., Petit, F. (2008): Motivating generation X and $\mathrm{Y}$ on the job and preparing Z. - Global Journal of Business Research 2(2): 139-148.

[31] Morgan, C. N., Ribbens, B. A. (2006): Generational Differences in the Workplace. Midwest Academy of Management, Louisville, KY.

[32] O'Bannon, G. (2001): Managing our future: the generation X factor. - Public Personnel Management 29: 55-74.

[33] Pekala, N. (2001): Conquering the generational divide. - Journal of Property Management 66(6): 30-38.

[34] Peters, K., Elands, B., Buijs, A. (2010): Social interactions in urban parks: stimulating social cohesion? - Urban Forestry \& Urban Greening 9: 93-100.

[35] Raines, C. (2002): Managing Millennials. - In: Raines, C. (ed.) Connecting Generations: The Sourcebook for a New Workplace. Principles, Tips, Methods, and Practices for Dealing with the New Multigenerational Workplace. Crisp Publications, Berkeley, CA.

[36] Reynolds, J., Stewart, M., MacDonald, R., Sischo, L. (2006): Have adolescents become too ambitious? High school seniors' educational and occupational plans, 1976 to 2000. Social Problems 53: 186-206.

[37] Roberts, J., Manolis, C. (2000): Baby boomers and busters: an exploratory investigation of attitudes towards marketing, advertising and consumerism. - Journal of Consumer Marketing 17(6): 481-499.

[38] Schroder, S., Warren, Z. (2005): Get to know Gen X - and its segments. - Multichannel News 26(12): 55.

[39] Senbir, H. (2004): Z The Last Person. - Okyanus Press, İstanbul. (Turkish).

[40] Sheahan, P. (2005): Generation Y: Surviving (and Thriving) with Generation Y at Work. $9^{\text {th }}$ Ed. - Hardie Grant Books, Australia.

[41] Smola, K. W., Sutton, C. D. (2002): Generational differences: revisiting generational work values for the new millennium. - Journal of Organizational Behavior 23: 363-382.

[42] Strauss, W., Howe, N. (1991): Generations: The History of America's Future. - William Morrow, New York, NY.

[43] Toruntay, H. (2011): Study of team roles: a comparative study on X and Y generation. Master Thesis, Istanbul University, Institute of Social Sciences, Department of Business Administration, Human Resources Management (Turkish).

[44] Türk, A. Y. (2013): Y Generation. - Kafekültür Press, İstanbul.

[45] Wallace, J. (2006): Work commitment in the legal profession: a study of baby boomers and generation Xers. - International Journal of the Legal Profession 13(2): 137-151.

[46] Wendover, R. W. (2001): Managing Millennials. - GenTrends Newsletter.

[47] Whyte, W. H. (1980): The Social Life of Small Urban Spaces. - The Conservation Foundation, Washington, DC, pp. 16-50.

[48] Wolburg, J. M., Pokrywczynski, P. (2001): A psychographic analysis of generation Y college students. - Journal of Advertising Research 41(5): 33-53. 
[49] Yuen, B., Chor, C. H. (1998): Pedestrian streets in Singapore. - Transportation 25: 225242.

[50] Zempke, R., Raines, C., Filipczak, B. (2013): Generations at Work: Managing the Clash of Boomers, Gen Xers, and Gen Yers in the Workplace. 2nd Ed. - Amacom, USA.

[51] Zhang, K., Bonk, C. J. (2010): Generational Learners and E-Learning Technologies. Handbook of Research on Practices and Outcomes in E-Learning: Issues and Trends. IGI-Global, USA, pp. 76-92.

[52] Zheng, Q. J., Xu, A. X., Kong, D. Y., Deng, H. P., Lin, Q. (2018): Correlation between the environmental knowledge, environmental attitude, and behavioral intention of tourists for ecotourism in China. - Applied Ecology and Environmental Research 16(1): 51-62. 